\title{
Martin Hultén
}

\section{The Epistolary Novels of Samuel Richardson: Reconsid- ering the Historical Perspective}

\begin{abstract}
English Summary
The epistolary novels of Samuel Richardson were received with enthusiasm throughout Britain and Europe upon their publication in the 1740s and 50s, and they have had their unquestioned place in the literary canon and the literary history of the 18th century, as well as in the many rivalling $R$ ise of the Novel narratives, ever since. The qualities of Richardson's novels praised by contemporary reading audiences and professional critics were to some extent the qualities we still acknowledge in the the works. And yet I propose to reconsider and modify our 'historical' understanding of Richardson's novels. Richardson scholars from the 1970s onward have deepened our understanding of the contexts of Richardson's life and writing, and they have shown to what extent both the style, the form, the motifs, and the themes of his novels must be placed alongside the works of rival authors, today much less known, and the comedies and tragedies of the restoration period, just to mention two important fields of inspiration for Richardson. On the basis of their findings we must conclude that the novels we read today when considering Richardson's works as part of a formal literary history are not quite the same as the novels contemporary readers cherished. There are important differences as well as correspondences between the contemporary reception of Richardson's works and the reception of professional scholars in the twentieth and twenty-first centuries.
\end{abstract}

\section{Martin Hultén}

Ph.d. i litteraturvidenskab. Post doc. ved Institut for Kunst- og Kulturvidenskab, Københavns Universitet. 


\section{Samuel Richardsons brev- romaner}

\section{En litteraturhistorisk placering}

På en måde er det oplagt at lægge vejen forbi Samuel Richardson, når talen er om romanernes historie og romangenrens form. Og så i en anden forstand giver det på ingen måde sig selv. Richardsons brevromaner fra midten af 1700-tallet er på den ene side uomgængelige, hver gang vi forsøger at etablere en historie, dvs. en litteraturhistorie om romanen eller romanerne eller det, vi er kommet til at identificere som (skøn)litteratur de seneste godt 200 år. På den anden side er Richardsons romaner ikke nogle, man uden videre læser frivilligt, med mindre man netop er professionelt interesseret i dem. Lige så populære romanerne var i hele det dannede Europa i det 18. århundrede, lige så ubærlige er de næsten at læse i dag. - Synes de fleste. Jeg selv har læst dem et antal gange og har ikke vanskeligt ved at beundre dem for deres håndværksmæssige mesterværk, selv om jeg måske nok kan have svært at identificere mig fuldt og helt med Pamelas, Clarissas og Sir Charles' glæder og sorger undervejs.

Med de sidste ord har jeg allerede antydet eller foregrebet, hvad det bl.a. skal handle om her: Læeserens identifikation med karaktererne i en roman. Jeg vil forsøge i korthed at diskutere brevromanernes litteraturhistoriske rolle og betydning, men lad mig først præsentere de romaner, det drejer sig om.

Samuel Richardson levede fra 1689 til 1761. Han var bogtrykker, hvilket er alt andet end en tilfældighed for romanernes måske lidt tilfældige tilblivelse. Det var forholdsvis sent i sit liv, han blev forfatter af det, vi kalder romaner (selv protesterede han voldsomt mod den betegnelse). Pamela; or, Virtue Rewarded udkom i 1740. Kun godt et år senere kom opfølgeren til samme, Pamela II, som stort set aldrig læses i dag og faktisk kan være lidt vanskelig at opdrive. I 1747-48 kom sa Clarissa or, The History of a Young Lady; af de fleste betragtet som hans hoved- og mesterværk; den længste roman i den engelske litteraturs historie, plejer man at sige. Endelig udsendte Richardson sin sidste store roman i 1754, denne 
gang med en mandlig helt og hovedperson: The History of Sir Charles Grandison; lidt kortere end Clarissa, men dog stadig et pænt stykke på den anden side af de 1500 tryksider. Heller ikke Grandison læses meget i dag, og den er i en årrække ikke blevet genoptrykt fra forlaget.

Historien om Pamela's umiddelbare succes både i England og hurtigt også på kontinentet er velkendt. Der var delvist tale om en skandalesucces pga. enkelte pikante - eller 'varme' som man sagde dengang - scener i romanen, hvor Mr. B. bliver lidt for nærgående overfor den stakkels tjenestepige. Men det er kun indirekte det pikante eller skandaløse, som er interessant i dag. Pamela og senere Clarissa og Grandison vakte straks opsigt pga. deres, syntes man, uhørte grad af realisme, især i personskildringerne, og det er netop denne realisme, som også for eftertiden fremstår som deres litteraturhistorisk mest interessante træk.

Selvom man altså allerede i samtiden og den umiddelbare eftertid havde blik for noget afgørende nyt i Richardsons romaner og fortællestil, så skyldes den litteraturhistoriske kanonisering og placering af hans romaner ikke mindst Ian Watt og hans The Rise of the Novel fra 1957. Som bekendt fremsætter Watt her den interessante og måske provokerende tese, at romanen, den moderne roman, opstår i England i det 18. århundrede; ikke tidligere end det 18. århundrede og ikke andre steder, f.eks. Spanien, Italien eller det antikke Rom. Det, der for Watt udmærker Defoes, Richardsons og Fieldings romaner - og dermed romangenren som sådan - er en »formel realisme «, dvs. ikke nødvendigvis en realisme i balzacsk eller zolask forstand i skildringen af den verden og de omgivelser, romanerne foregår i, men en realisme i måden, historien bliver fortalt på. ${ }^{1}$ Det, der i den sammenhæng er Richardsons særlige og vigtigste fortjeneste, er at have givet plottet en særlig koncentration omkring én central intrige og mest interessant at have opfundet en fortællestil, der muliggjorde en høj grad af realisme i personskildringen. Pamela, Clarissa og de øvrige personer, der kommer til orde i brevromanerne, fremstår for læserne med en psykologisk dybde, om man vil. De er skildret nuanceret og varieret, dvs. de er individualiserede og ikke - det er den af Watt tænkte modsætning - todimensionale og uforanderlige typer. ${ }^{2}$

Lad mig kort forsøge at give et par eksempler på den fortællestil, Richardson måske i første omgang næsten falder over lidt tilfældigt og derefter udvikler og perfektionerer. Han selv og samtiden lagde særlig vægt på to træk ved fortællestilen: Dels førstepersonperspektivet og dels nutidsformen. Begge dele bidrog til at skabe et nærvær og en intimitet i forhold til figurerne og dermed til at skildre dem virkelighedsnært og nuanceret.

Både Pamela, Clarissa og Harriet Byron (den måske egentlige hoved- 
person og vigtigste brevskriver i Sir Charles Grandison) er moralsk og religiøst eksemplariske karakterer, der skriver åbent og ærligt om deres inderste tanker og følelser til de personer, de brevveksler med. Så åbent og ærligt, som de føler sig i stand til, og allerede her ligger en høj grad af intimitet i personskildringen. Men Richardson er også med det samme opmærksom på det potentiale, der kan ligge i, at en person udleverer sig selv hinsides vedkommendes egen bevidsthed og klart erkendte viden. I alle tre romaner handler det bl.a. om, at hovedpersonerne er forelskede, men kun halvt om halvt og først hen ad vejen er eller bliver sig deres følelser bevidst. I denne gradvise erkendelsesproces er de personer, de skriver til - og dermed også læserne af romanen - altid et skridt forud; vi kan se de blottelser, hovedpersonerne uafvidende eller ubevidst kommer med i deres ordrige overvejelser og bekendelser.

Richardson var efter hans egne udsagn at dømme af den opfattelse, at en persons skrivestil og breve udleverede vedkommendes personlighed fuldstændig transparent og som sagt ofte hinsides dennes egen bevidsthed. Men han var sjovt nok også - og det bemærker jeg kun parentetisk her - samtidig opmærksom på, at breve og skrivestil kunne forfalskes og bruges som maske, dvs. til at dække over personligheden. ${ }^{3}$ Det er det første, jeg vil dvæle ved, og lad mig give et eksempel fra Clarissa. Heltinden er kommet til at afsløre en lidt for stor interesse og lidt for varme følelser for libertineren Lovelace i et brev til veninden Anna Howe. Anna skriver drillende tilbage og udbreder sig over de bemærkninger, der i hendes øjne afslører Clarissa. Clarissa svarer overrasket og næsten lidt pikeret:

»[...] de passager i mit brev, du er så drilagtigt hård ved, blotter mig i nogen grad for dine behagelige drillerier. Det indrømmer jeg. Og jeg kan ikke forstå, hvad der har grebet mine tanker, at de skulle diktere så mærkværdigt til min pen. «4

Eksempler af denne art optræder i alle tre romaner. Personerne afslører sig selv og deres følelser uden at vide det og bliver derefter konfronteret med det i efterfølgende breve. Læseren af romanen bliver uden videre gjort til en medvider og fortrolig, der ligesom brevets modtager kan se dybere i brevskriveren end vedkommende selv.

Faktisk optræder passager som den citerede oftere i den første og den sidste roman end i Clarissa. Pamela og Sir Charles Grandison er komedier, om man vil, de ender lykkeligt, dvs. de elskende får hinanden, og derfor er der ikke noget problematisk i de kun halvt erkendte følelser for romanens handling og karakterens personlighed. Omvendt i Clarissa, hvor Lovelace er en skurk, og hvor kærligheden ikke skal sejre til slut. 
Her bliver opgaven at beherske, besejre og betvinge de farlige følelser, og det er en beherskelse, der interessant nok skifter omfang og karakter i takt med, at Richardson retter, korrigerer og udsender stadig nye versioner af romanen. Den stil, der kunne afsløre mere om brevskriveren, end vedkommende var sig fuldt bevidst, kunne tilsyneladende også tage fusen på forfatteren selv.

\section{"Denne levende presens måde"}

Men nok om det. Det andet træk ved fortællestilen, der måske i endnu højere grad slog samtidens læsere som nyt og revolutionerende, og som Richardson selv var stolt af at have opfundet, var nutidsformen, som eksempelvis Lovelace i Clarissa selv- og stilbevidst kommenterer:

"Du vil kunne konstatere, Belford, at selvom dette er skrevet efterfølgende, så skriver jeg det (her som andetsteds), som det var talt og skete, som om jeg havde trukket mig tilbage umiddelbart og nedfældet hver eneste sætning, som den blev talt. Jeg ved, du holder af denne levende presens måde, eftersom den er et af mine særkender. $\ll^{5}$

Nutidsformen var et middel til at opbygge en spænding i fortællingen. Når personerne i romanerne skrev »to the moment ", som de selv og Richardson kaldte det, kunne de opbygge en suspense i det fortalte og som konsekvens et nærvær og en realisme, der virkede stærkt på læsepublikummet. Men nutidsformen truede også romanernes realisme i en anden forstand. I et brev skriver man nødvendigvis i tilbageblik, rekapitulerende, når de begivenheder, man vil berette om, er overståede, og da kan det være vanskeligt at opbygge spænding. Richardson forsøgte at omgå denne formelle begrænsning ved at lade sine personer skrive stort set altid og stort set samtidig med, at de oplevede det, de skrev om. Navnlig i Pamela, den første og fortælleteknisk mest klodsede roman af de tre, giver det ind imellem næsten komiske resultater, hvilket kun delvist fremgår af de udgaver af romanen, der oftest er tilgængelige i dag. De følger gerne en af Richardson gennemrevideret og korrigeret version, der først udkom længe efter hans død i 1801. Her er dog et dramatisk øjeblik, der er sluppet gennem alle revisioner:

»Mrs Jewkes er blevet kaldt ned. Hestetramp på gårdspladsen. Der er besøgende. En vogn med seksspand. Adelige våbenskjold på vognen. Hvem kan det være? De er steget ud og er gået ind i huset. 
Frygteligt! Frygteligt! Hvad skal jeg gøre? Lady Davers! Lady Davers i egen høje person! Og min gode beskytter mange, mange mil borte! $\ll^{6}$

Ingen tvivl om, at Richardson formåede at gengive øjeblikkets intensitet og spænding med Pamelas stakåndede syntaks, men også på bekostning af realismen. Selvom Pamela »elsker at skrive « ligesom alle Richardsons øvrige centrale karakterer, så vil de færreste reflekterede læsere acceptere, at hun sidder og skriver, mens hun samtidig gennemlever de for hende mest højdramatiske begivenheder.

Henry Fielding og mange andre var hurtige til at se det komisk absurde i den overdrevne »writing to the moment «. I Fieldings parodi Shamela, der udkom ganske kort tid efter Pamela, er bl.a. den mest berømte, skandaløse, pikante scene fra Pamela gengivet i karikeret form. Her fortsætter Pamela/Shamela ufortrødent med at skrive, selv da Mr. B - Booby hos Fielding - ligger i sengen ved siden af hende og allerede er gået over til behagelige håndgribeligheder:

»Mrs. Jervis og jeg er netop gået i seng, og døren er ulåst for det tilfæxlde, at min herre skulle komme - Odsbobs! jeg kan høre, han kommer ind ad døren. Du ser, at jeg skriver i nutid, som pastor Williams kalder det. Nå, han er i sengen mellem os, vi prøver begge at lade som $\mathrm{om}$, vi sover, han sniger en hånd ind på mit bryst $[\ldots] \ll^{7}$

Fielding rammer et svagt punkt i Richardsons på det tidspunkt overdrevne brug af nutidsformen, men det ændrer ikke ved, at fortællemåden for mindre reflekterede og mindre æstetisk bevidste læsere bidrog til at skabe både spænding, nærvær og realisme i fortællingen og skildringen af personerne.

\section{Roman og romance}

Som nævnt er det ikke mindst Ian Watt, der i det 20. århundredes litteraturhistorie har bidraget til at stadfæste det, der et stykke hen ad vejen også var Richardsons egen selvforståelse; nemlig at han fornyede - eller skabte, hvis man som Watt vil sætte sagen på spidsen - romangenren og tilførte den særligt det træk eller element, at romanen har skildringen af realistiske karakterer som et af sine væsensbestemmende træk.

Watts tese er jo blevet ivrigt imødegået og diskuteret i det halve århundrede, der er gået, siden The Rise of the Novel udkom første gang. Det er ikke svært at komme i tanker om en rakke mulige indvendinger mod 
Watts tese. Man kan pege på og har peget på, at eksempelvis skildringen af realistiske karakterer ikke er enestånde for Richardson, ikke er enestående for engelske romaner, ikke først optræeder så sent som i det 18. århundrede og ikke eksklusivt er knyttet til værker, vi grupperer under romangenren.

Mere specifikt kan man fremdrage, at heller ikke de konkrete fortælletekniske nyskabelser, vi forbinder med Richardson, og som jeg netop har givet eksempler på, unikt og eksklusivt er hans 'opfindelser'. Det sidste er blevet gjort i Richardsonfilologien bl.a. Det er blevet påpeget, hvordan Richardson i et vist omfang overtager både form og motiver fra sin samtids dramaer og beslægtede prosaværker. ${ }^{8}$ Eksempelvis er de centrale intriger og figurerne i deres indbyrdes forhold i Richardsons romaner direkte overtaget fra bl.a. de populære komedier og tragedier fra restaurationstiden, dvs. fra perioden efter 1660. - Dramaer der i parentes bemærket kun læses af specialister i dag, hvilket naturligvis bidrager til, at Richardson kan fremstå som enestående eller original i flere henseender, end han faktisk var det. Derudover bør dominerende 1700-tals genrer som religiøs opbyggelig litteratur samt de særlige conduct books nævnes som vigtige inspirationer for Richardson. Ikke mindst de sidstnævnte 'håndbøger i god opførsel' minder, hvad indholdet angår, meget om belæringerne i alle tre romaner, og Richardson havde i øvrigt selv bidraget til genren med sin The Apprentice's Vade Mecum; or, Young Man's Pocket Companion fra 1733. Det var hans første bog, og heri giver han gode råd om, hvordan en ung mand bør opføre sig i alle livets forhold, særligt dem der har at gøre med ansættelsesforholdet til en håndværksmester. Richardson var selv bogtrykker og arbejdsgiver for en række unge lærlinge.

Mere interessant er det måske, at en lang række af periodens romances (som de plejer at hedde i engelsksproget kritik) indeholder stort set alle de elementer, vi forbinder med Richardsons særegne mesterskab. I 1710'erne, 20'erne og 30'erne, dvs. i årtierne inden Richardson skrev sin første roman, blev der udsendt en mindre syndflod af romances skrevet af forfattere som Penelope Aubin, Jane Barker, Mary Davys og mest kendt Eliza Haywood. Disse kvindelige forfattere var i markant grad påvirket af de store franske romaner (plejer vi at kalde dem på kontinentet) fra det 17. århundrede med Mme de La Fayettes Fyrstinden af Clèves (1678) og den anonyme Portugisiske breve (1669) som de mest kendte og indflydelsesrige i netop den linie i genrehistorien. I et snævert engelsk perspektiv havde Aphra Behn og Mary de la Rivière Manley i de sidste årtier af det 17. århundrede så at sige åbnet den mulighed, at man som kvinde kunne leve af at være forfatter. Det er vigtigt at have in mente, når vi kigger på Richardson i et både historisk og litteraturhistorisk perspektiv. ${ }^{9}$ 
I de kvindelige forfatteres romances eller romaner finder man som sagt alle de elementer, vi senere forbinder med Richardsons romankunst. De Portugisiske breve havde affødt en veritabel bølge af brevromaner, og breve bliver ofte benyttet i de engelske kvinderomaner fra starten af det 18. århundrede. Her er det så godt som altid en kvindelig hovedperson, der er involveret i én af to mulige intriger: Enten drejer det sig om en xgteskabshistorie, en courtship novel, eller om en forførelses- eller voldtægtsroman. Hovedtyper vi genfinder hos Richardson. Hos de kvindelige forfattere finder vi også udstrakt brug af førstepersonperspektivet, det siger sig selv med brevformen som medium, og ind imellem også nutidsformen, som Richardson senere næsten tager patent på. ${ }^{10}$

Ian Watt synes i The Rise of the Novel kun at have blik for de forskelle, der udmærker Richardsons romaner til fordel for periodens engelske og franske romances, prosafortællinger, romaner. Det forekommer ikke helt fair. Watt arbejder med en skelnen mellem novels og romances, som stort set altid har været almindelig i den engelsk-amerikanske litteraturhistorie og kritik, som nævnt, men som vel ikke findes tilsvarende i eksempelvis Tyskland og Frankrig? Margaret Anne Doody, som er en af dem, der har peget på forbindelsen og slægtskabet mellem Richardson og periodens andre værker i forskellige genrer og subgenrer, fastholder, at Richardsons mesterskab og historiske betydning er uomtvistelig. Hun fremhæver, at hans særlige kvaliteter netop lader sig præcisere på baggrund af de værker, han så godt som helt sikkert havde læst og bevidst eller ubevidst var påvirket af. Richardson formår at samle de elementer, som ellers kun findes spredt hos de nævnte kvindelige forfattere, og han udvikler det fulde potentiale, der ligger i de teknikker, jeg kort har nævnt. I romancerne havde man haft vanskeligt ved at mestre både plot og karakterer i samme fortælling. En vellykket personskildring var her ofte realiseret på bekostning af plottets sammenhæng og især naturligvis forløb og udvikling. ${ }^{11}$ Richardsons romantekniske formån viser sig ikke mindst $\mathrm{i}$ hans evne til at fastholde et stramt komponeret plot med en enkel og konsekvent intrige i Pamela samtidig med, at der dvæles ved den detaljerede og virkelighedsnære skildring af heltinden som romanens altdominerende brevskriver. I Clarissa kompliceres plottets opbygning væsentligt, idet der her skrives og sendes breve til og fra en række hovedpersoner, og alle disse karakterer bliver skildret levende og individualiseret bl.a. ved hjxlp af en personlig tone og brevstil tilpasset hver enkelt.

\section{Realisme og opbyggelighed}

Richardsons romaner kan altså skrives ind i en historie og litteraturhi- 
storie, hvor de bliver skrevet med tydelig inspiration fra og slægtskab med tidens dramaer og romances. Spørgsmålet er, om det er den eneste eller den mest relevante og interessante historiske placering af dem. Selv ville Richardson havde protesteret voldsomt mod at blive sammenlignet med eller måske endda sat $\mathrm{i}$ bås med de kvindelige forfattere. I sin egen selvforståelse skrev han værker, som bestemt ikke kunne kaldes hverken novels eller romances. ${ }^{12}$

Idet han distancerer sig fra samtidens lettere genrer, fremhæver og insisterer han på det opbyggelige i sine fortællinger. Det var selvfølgelig langt fra enestående, tværtimod er det vel det mest genkommende træk ved både franske og engelske romanforfattere - skal man tro forordene til romanerne i perioden - altså at de så at sige undskylder beskæftigelsen med en lav genre som romanen med henvisning til det opbyggelige og belærende i fortællingen. ${ }^{13}$ Hos Richardson er imidlertid ordene alvorligt ment, og det interessante er, at han argumenterer udførligt for, at netop realismen i personskildringen og intrigen er nødvendige betingelser for, at værket som helhed kan fungere belærende og instruktivt. Kun hvis læseren kan genkende og identificere sig med heltinden og føle med hende i hendes medgang og modgang, vil han eller hun også kunne benytte læsningen til personlig opbyggelse.

Der er grund til i hvert fald et stykke hen ad vejen at tage Richardsons selvforståelse alvorligt. Han var selv af den opfattelse, at han skrev historier eller fortællinger - han benytter som anført i noten ovenfor ordene history og dramatic narrative om eksempelvis Clarissa - altså fortællinger, hvor det - skal vi for nemheds skyld sige: - realistiske var uløseligt knyttet til det opbyggelige ærinde. Og hvad der måske er vigtigst: Sådan blev værkerne også læst eller i hvert fald ofte læst. Det er velkendt, hvordan selskabslivet i London nærmest delte sig i pamelister og anti-pamelister i de første år af 1740'erne, og da Clarissa senere udkom var den genstand for intens debat om heltindens handlemåde og sindelag. ${ }^{14}$ Man svælgede naturligvis i de pikante scener, man lod sig rive med af dramaet og identificerede sig med personerne. Men man diskuterede også romanens moral.

Et berømt eksempel på dette dobbelte eller flersidede blik på romanerne finder vi i Diderots Hyldest til Richardson, skrevet i anledning af Richardsons død d. 4. juli 1761. Diderot skriver henført om, hvordan han i halve og hele døgn har været fuldstændig opslugt af læsningen af Richardsons romaner, hvordan han har levet sig ind $\mathrm{i}$ handlingen og følt med heltinden, og det er i sig selv interessant som påmindelse for den nutidige læser, der måtte mene, at det eneste perverse ved Clarissa er dens længde. Men Diderot er som philosophe også glad for romanernes opbyg- 
gelighed og moral, dvs. i virkeligheden priser han frem for alt formens betydning for indholdet: »Alt hvad, Montaigne, Charron, La Rochefoucauld og Nicole har udtrykt i maksimer, har Richardson ladet komme til udtryk i en handling ${ }^{15}{ }^{15}$ Den tørre moralfilosofi har Richardson gjort levende ved at knytte den til en romanintrige og lægge den i munden på realistisk skildrede karakterer, som man uden videre genkender fra sin egen livsverden. ${ }^{16}$ Diderot går så langt som til at udtrykke det håb, at et forfatterskab som Richardsons dagligt vil kunne bevirke hundrede gode gerninger, hvis det bliver udbredt og læst; han har selv erfaret, hvordan han ved læsning af romanerne bliver mindet om dyden og moralen som menneskets egentlige og sande lykke, ligesom han omtaler et konkret tilfælde, hvor en kvinde har afbrudt en uheldig alliance efter læsning af Richardson. ${ }^{17}$

Når vi forsøger at placere Richardson litteraturhistorisk, er vi tilbøjelige til at glemme romanernes didaktik, vel bl.a. fordi vi finder hans fromme puritanisme næsten ubærlig. Dvs. vi fastholder et formbistorisk blik på det fortælletekniske mesterskab og opfatter det didaktiske som et kulturog socialhistorisk kuriosum. Hvis det er sandt, kunne det antyde, at den forståelse, der omgav Richardsons brevromaner i deres samtid ikke i alle henseender stemmer overens med den forståelse, vi knytter til dem, når vi placerer dem centralt i romangenrens historie.

\section{Historie og virkningshistorie}

Det jeg foreslår her, er at skelne mellem brevromanernes historie og deres virkningshistorie. ${ }^{18}$ Richardsons romaner var anderledes og nyskabende, både når man betragter dem fra deres samtid og deres eftertid, men samtidens og eftertidens blik er alligevel ikke helt det samme. Set fra samtiden lader Pamela, Clarissa og Grandison sig kun tvetydigt placere i en romanens historie, for genren havde ikke nogen entydig historie omkring 1740. Richardson skrev på baggrund af og mere eller mindre bevidst inspireret af periodens romances (igen: kalder vi dem), der igen var kraftigt påvirket af en række franske romaner fra det 17. århundrede, men han forsøgte samtidig at lægge kraftig afstand til denne tradition.

Til gengæld ved vi nu, at hans romaner fik en næsten uoverskuelig virkningshistorie, ikke mindst i Frankrig og senere Tyskland. Tænk blot på Diderots La religieuse, Rousseaus La Nouvelle Héloise, Goethes Werther og Laclos' Les liaisons dangereuses fra hhv. 1760, 1761, 1774 og $1782 .{ }^{19}$ Richardson var ikke den første til at interessere sig for romankarakterernes indre liv, deres psykologi om man vil. Men han var og er en virkningshistorisk indflydelsesrig forfatter, hvad netop dette træk angår. Han indskri- 
ver sig i en hovedlinie i romangenrens historie, som vi nu forstår den.

Ikke alle romaner og ikke alle moderne romaner har karakterernes indre liv som deres hovedinteresse. Der er forskel på Richardson og Fielding, ligesom der er forskel på Balzac og Stendhal eller på Tolstoj og Dostojevski. De nævnte forfattere interesserer sig i varierende grad og navnlig på forskellig måde for deres personers psykologi. Det mest interessante historiske blik på Richardsons brevromaner er for mig at se, at de indgår i den hovedlinie eller hovedåre - en hovedåre blandt flere andre vel at mærke; der er ikke tale om at jeg fremhæver en bestemt slags romaner på bekostning af alle andre - i romanernes historie, hvor man ser skildringen af karakterernes indre liv som en væsentlig, af og til den væsentligste eller mest interessante opgave for romanen.

Richardson benytter brevromanen som middel til at nå dette mål, og med ham får den subgenre en fornyet aktualitet og popularitet i det 18 . århundrede, jvf. blandt andet de fire værker jeg nævnte ovenfor. Brevromangenren dør mere eller mindre ud ved udgangen af 1700-tallet. Af og til hævder man, at det skyldes Laclos' uomtvistelige mesterskab; efter Farlige forbindelser var genrens muligheder om ikke udtømt så i hvert fald udnyttet til fulde, og forfatterne måtte søge andre veje. Selv køber jeg ikke helt denne tese, bl.a. fordi den stiltiende forudsætter en geniæstetik og et originalitetsimperativ, som først så småt var ved at etablere sig på dette tidspunkt. Mere sandsynligt forekommer det, at brevgenrens begrænsninger i fortælleperspektivet måtte føles som en hæmning, og man forsøgte sig med andre fortællepositioner og -teknikker.

Men hvordan skildre karakterernes indre liv virkelighedsnært, når man ikke længere benytter førstepersonperspektivet? Her forekommer det mig, at man må føre linien frem til Flaubert, der ganske vist ikke opfandt, men i særlig grad mestrede style indirect. Og fra Flaubert kan vi tegne linien længere frem til først James og siden Woolf og Joyce for blot at nævne nogle af de mest markante. Der er en indiskutabel påvirknings- og virkningshistorie fra Richardson til Rousseau og Goethe og videre frem til eksempelvis Jane Austen og særligt Flaubert. Og derefter som det vil være bekendt fra Flaubert til James osv. I denne tradition interesserer man sig i særlig grad for gengivelsen af en romanfigurs indre tanker, følelser og kun halvt bevidste eller ubevidste sjælelige tilstande. De fortælletekniske midler skifter undervejs i løbet af de knap tohundrede år, jeg forsøger at omfatte her, men interesserne eller ærindet er på et alment plan de eller det samme. Eller sagt på en anden måde for evt. at slå et slag for de komparative litteraturstudier som videnskabeligt felt og som dimension og disciplin i litteraturvidenskaben: De nævnte forfatterskaber er sammenlignelige. ${ }^{20}$ 
En virkningshistorie som den, jeg skitserer her, kan man i sagens natur kun tegne i retrospekt. Lad mig derfor præcisere, hvorved virkningshistorien adskiller sig fra den historie, Richardsons romaner indgår i i samtiden. Her er det måske på sin plads at minde om Pamela's oprindelseshistorie. Richardson blev bedt af en forlægger om at forfatte en manual eller en vejledning i brevskrivning. Sådanne manualer var almindelige og havde været det siden begyndelsen af det 17. århundrede; de indeholdt typiske breve, som de kunne være udformet, komponeret og formuleret fra en datter til sine forældre, fra en ven til en anden ven, fra en person til en offentlig instans osv. Richardson påtager sig opgaven, og han ender også med at fuldføre den, men hans Familiar Letters on Important Occasions udkom først efter Pamela. Der skete det undervejs, at brevene i manualen fra en datter til sine forældre så at sige var vokset mellem hænderne på ham og havde tiltrukket sig en særlig interesse.

Oprindelseshistorien er vigtig og interessant, bl.a. fordi den viser, hvordan Richardson nødvendigvis måtte arbejde med at give sine personer et individuelt udtryk og en individuel stil. Det lå i kravet til en manual indeholdende forskellige breve fra forskellige personer i forskellige typiske situationer, og det blev ét af de træk, der særligt udmærkede Richardsons senere romaner. Ikke at han var den første til at tænke i de baner, som Watt lader os tro, men han lykkedes i særlig grad i den henseende, og eksempelvis Pamelas brevstil fremstår fortsat i dag med en ægte friskhed i udtrykket, hvilket er én af romanens kvaliteter. Lige så interessant i denne sammenhæng er, at afsættet i manualen understreger, at det instruktive eller belærende var udgangspunkt og fundament, ikke et tilfældigt og heldigt biprodukt af en spændende fortælling.

\section{Afrunding}

Jeg nærmer mig en afsluttende præcisering. Richardsons romaner har deres genrehistoriske oprindelse i et broget felt af romaner og romances, komedier og tragedier fra samtiden, religiøse opbyggelsesskrifter, conduct books og så manualer i brevskrivning. Resultatet bliver en fortælling - en roman, siger vi - med en særlig grad af realisme, syntes man i samtiden, og senere hen en virkningshistorie som den, jeg har forsøgt at skitsere.

Når jeg skelner mellem historie og virkningshistorie, så er det ikke for at hævde en absolut forskel mellem de to. Jeg mener, at man i Richardsons tilfælde kan tale om et delvist sammenfald mellem og især en kontinuitet mellem historie og virkningshistorie. Samtidens opfattelse af romanerne stemmer på visse punkter overens med og peger frem mod eftertidens. Richardsons romaner placerer sig i en allerede eksisterende 
historie, men som alle markante værker i litteraturhistorien ændrer de også den historie, de træder ind i. Romanernes og romangenrens historie starter ikke med Richardson, men han bidrager til og er overhovedet en af de væsentligste forfattere i det, jeg her har kaldt en hovedlinie i genrens brogede, heterogene historie.

\section{Noter}

1 Ian Watt: The Rise of the Novel, London 2000 (org. 1957) pp. 9-34.

2 Ibid. pp. 18-21; pp. 174-207 (særligt p. 19lff.); p. 238 og måske mest interessant p. 262ff., hvor Richardsons skildring af karakterer bliver sammenlignet med Fieldings.

3 Tom Keymer har i en overordentlig interessant bog analyseret Richardsons fortællestil i Clarissa. Hans analyser er for så vidt et korrektiv eller i hvert fald et supplement til den lidt hurtige opfattelse af stilen som et umiddelbart og gennemsigtigt medium for personligheden. Analyserne er for specielle til at blive inddraget i denne artikel, hvor en litteraturhistorisk linie er hovedsagen, men bogen er uomgængelig for enhver, der ønsker at kigge nærmere på Richardsons forfatterskab og brevromanen i det 18. århundrede: Tom Keymer: Richardson's Clarissa and the Eighteenth-Century Reader, Cambridge, New York m.fl. 1992. Jeg skylder Professor Knut Ove Eliassen, Trondheim, tak for at have gjort mig opmærksom på den.

4 Samuel Richardson: Clarissa, or, The History of a Young Lady, London, New York m.fl. 1985 (org. 1747-48) p. 72.

5 Ibid. p. 882.

6 Samuel Richardson: Pamela; or, Virtue Rewarded, London, New York m.fl. 1980 (org. 1740) p. 401.

7 Henry Fielding An Apology for the Life of Mrs. Shamela Andrews, Oxford, New York m.fl. 1980 (org. 1741), p. 330. Jeg har hverken villet eller kunnet oversætte Shamelas udbrud odsbobs, som Fielding har taget fra Richardson og Pamela. Ian Watt citerer og kommenterer i forbifarten samme passage fra Shamela. Se evt. The Rise of the Novel p. 25.

8 Margaret Anne Doody: A Natural Passion. A Study of the Novels of Samuel Richardson, London 1974, pp. 14-34; pp. 36-40; pp. 107-127; pp. 128-150. I det følgende refererer jeg især Doodys præcise bemærkninger. Se evt. også T.C. Duncan Eaves \& Ben D. Kimpel: Samuel Richardson. A Biography, Oxford 1971, p. 115ff.; p. 583ff.; p. 600ff.

9 Margaret Anne Doody: A Natural Passion. A Study of the Novels of Samuel Richardson, London 1974 p. 17f.

10 Ibid. p. $22 \mathrm{f}$.

11 Ibid. p. 24; p. 35f.; p. 129.

12 Se evt. efterordet til Clarissa: Samuel Richardson: Clarissa, or, The History of a Young Lady, London, New York m.fl. 1985 (org. 1747-48) pp. 1495-99. Her benytter Richardson ordene history og dramatic narrative om sin roman, som han derudover forsøger at placere i tragediegenrens tradition. Han vil mao. hellere associeres med den høje stil i tragedien end en lav genre som 
romanen (the novel) og romancen. Se evt. også Margaret Anne Doody op. cit. pp. 128-150.

13 Se til eksempel Daniel Defoe: The Fortunes and Misfortunes of the Famous Moll Flanders, London 1989 (org. 1722) p. 38ff.; Abbé Prévost: Histoire du Chevalier Des Grieux et de Manon Lescaut, Paris 1972 (org. 1731) p. 4lff.; og Choderlos de Laclos: Les liaisons dangereuses, Paris 1987 (org. 1782) p. 4ff.

14 Se hertil Sarah Fielding: Remarks on Clarissa, Los Angeles 1985 (org. 1749) som et markant eksempel.

15 Denis Diderot: »Éloge de Richardson«, in Euvres esthétiques, Paris 1994 (org. 1762 ) p. 29. Det skal huskes, at Rousseaus La Nouvelle Héloïse var udkommet i februar 1761, så Diderots hyldest til Richardsons realisme kan og bør også læses som en kritik af den tidligere vens, nu fjendes, arkadiske fantasier. Se især Diderot op. cit. p. 30.

16 Henry Fielding, der ofte lidt fejlagtigt opfattes som rival til Richardson - personligt og/eller romanpoetologisk -, udtrykker i et brev til Richardson kort efter Clarissa's offentliggørelse bl.a. sin beundring for skildringen af personerne og fremhæver ligesom Diderot realismen og genkendeligheden. Se evt. T.C. Duncan Eaves \& Ben D. Kimpel: Samuel Richardson. A Biography, London 1971, p. $294 \mathrm{f}$.

17 Diderot op. cit. p. 42.

18 En skelnen som bl.a. er inspireret af Tue Andersen Nexøs diskussion af Defoes Robinson Crusoe i dette nummer af $K$ \& $K$.

19 Denis Diderots La religieuse er skrevet i 1760, men blev som så mange andre af Diderots betydelige skrifter først offentliggjort efter hans død; den blev udgivet i 1796.

20 Allerede Ian Watt antyder, ligesom mange andre har gjort, dette litteraturhistoriske perspektiv på Richardsons romaner i slutningen af The Rise of the Novel. Se evt. også Tom Keymer op. cit. p. 5 f. 